\title{
Ikhwanul Muslimin Policy on Halal Tourism in Arab Republic of Egypt
}

\begin{abstract}
Shubhi Mahmashony Harimurti
Department of Pharmacy, Faculty of Mathematics and Natural Sciences, Universitas Islam Indonesia

Abstract: This research's purpose to inform how Ikhwanul Muslimin (Moslem Brotherhood) policy on halal tourism in Arab Republic of Egypt. As we know that Ikhwanul Muslimin is an Islamic movement that is identified by some countries as a radical group. So, it is interested theme because logically the Islamic movement should realize halal tourism. Ikhwanul Muslimin's bargaining position when they ruled Egypt in Muhammad Mursi regime is a great milestone. Issue about Ikhwanul Muslimin that dislike to 'haram' tourism influenced on agents of tourism industry. Inductive reasoning and macro scale is utilized in this research. Functionalism is used as an analyze knife. The value of this research that can contribute to public is issue of halal tourism policy could stabilize the governance.
\end{abstract}

Keywords: Egypt, Halal, Ikhwanul Muslimin, Policy, Tourism.

\section{Introduction}

The concern on the aftermath of political upheaval of 2011 is based on several indications that the historic event adversely affects the tourist industry in the Arab Republic of Egypt. There has been a growing concern of tourism industry players in the Arab Republic of Egypt against the victory of Ikhwanul Muslimin in the legislative election (November 2011) and executive election (May - June 2012). Another factor underlying the selection of the theme is the fact that after the political upheaval of 2011, there was a significant change to a number of policies in the Arab Republic of Egypt. Some examples of such changes are freedom of association, opinion, assembly, and use of Islamic symbols in the society.

This study uses two different perspectives of both insider and outsider aspect. The insider perspective is aimed to address the concerns of the parties involved in the tourism industry of the Arab Republic of Egypt after the Ikhwanul Muslimin's victory in Legislative Election (2011) and Executive Election (2012). They pay a great concern that the victory of Muslim's Brotherhood will lead to the slackening tourism industry of The Arab Republic of Egypt. This is due to the assumption that the victory of Hizb al-Huriyah wa al-'Adalah (The Freedom and Justice Party) which is the political wing of the Ikhwanul Muslimin will impede the development of the tourism industry. What they have in mind is that the Ikhwanul Muslimin will surely prohibit all tourism activities or objects for being considered as unlawful. This ranges from drinking liquor, consumption of pork or dogs, belly dance, tourist destinations not originated from Islamic era, to the habits of Western tourists to travel on the beach on bikinis and shorts. In other words, the Ikhwanul Muslimin is deemed as synonymous with the halal tourism policy that may threaten the existence of the previous tourism industry.

Such assumption is reasonably based on the widely understood notion that the Ikhwanul Muslimin is based on the conservative Islamic Ideology which may threaten the existence of the major cultural attractions of the Arab Republic of Egypt originating from the pre-Islamic period. This is so because Islamic groups have always been seen as naively related to the tourism industry.

Thus, tourism industry actors are worried that there will be an abandonment of the cultural attractions of the pre-Islamic period since the government will pay sole attention to the historical relic from the Islamic era of the Prophet Muhammad. Such concerns are also incurred by fear for the ever-occurring case of collapsing tourist industry in other countries due to lack of conservation effort from the local authorities. Some tourist attractions such as Pharaoh's legacy are feared to be ruled out because they may be judged to be idolatrous. 
Another reason for the concern on the future tourism industry of the Arab Republic of Egypt is due to the emergence of the hardline Muslim group who disagree with the existence of cultural attractions both originating from the previous Islamic era and the contemporary era of Islam. They assume that some tourist objects cannot be justified by the teachings of Islam for being immoral.

Such growing assumption is well-based on the widely known brutality of Hardline Muslim groups against the religiously unlawful tourism objects as can be seen from the outbreak of terrorist attack of Bali Bomb I and II of 2002 in Indonesia. Such cases are comparable with the similar symptoms that occur in the Arab Republic of Egypt.

The last concern of the tourism industry players of the Arab Republic of Egypt against the victory of the Ikhwanul Muslimin deals with the possibility that there will be regulations not in favor of tourism industry issued by either the executive or legislature. According to information from Firmansyah [1, p. 24], Arab Republic of Egypt is indeed controlled by the Ikhwanul Muslimin, but currently still there are strong political sentiments of liberal groups. The political interest between the two groups greatly colors the play of political elites, especially in the field of tourism industry. In fact, the dominating shadow of the old regime (Mubarak) in the new civilian government (Mursi) is pretty powerful which may lead to various frictions [2, p. 20]. No wonder, still there has been political contestation in the first civilian government in the Arab Republic of Egypt after 59 being in the grip of the military regime.

Based on the interviews, it is revealed that both the Ministry of Tourism and the Ministry of Antiquities of the Arab Republic of Egypt is mostly still filled by the loyalists of the previous Egyptian President, Hosni Mubarak. Thus, it is feared there will be a politics of revenge or one-sided policy from the ruling party dominated by the Ikhwanul Muslimin. The Ikhwanul Muslimin group which is known to be the supporters of Mursi is openly opposed by the Mubarak loyalists [3, p. 7] and [4, p. 20].

The second perspective is the outsider which describes the perception of foreign parties towards the Arab Republic of Egypt post-political upheaval of 2011. This perspective is based on the condition of the Arab Republic of Egypt after the political upheaval of 2011 along with its consequences in the field of tourism industry. The disclosure of both insider and outsider perspective is a form of contradictory fact-finding which may lead to objective facts and data.

This research aims to shed light on the policy of the ruling party, the Ikhwanul Muslimin, in terms of halal tourism. This research is expected to reveal the direction of tourism industry of the Arab Republic of Egypt to the public and the stakeholders, since the issue of halal tourism policy can affect the stabilization of a country's government.

\section{Literature Review}

Literature review is aimed to determine the extent to which the research object has been discussed by other researchers. A book written by Setiawati [5] under the title of Mekanisme Consociational dalam Penyelesaian Konflik Insider Lebanon is mainly used as a literature review. It is in line with the current research, since this previous research mentions that political upheaval can have an impact on the social and religious fields. What makes the former differ from the current is that the former does not explain about the state of Lebanon's tourism industry during the outbreak of internal conflict.

The book published by the Ministry of Tourism of the Arab Republic of Egypt [6] is also referred as a literature review. This book completes and details about the state of the tourism industry in the Arab Republic of Egypt especially the data of tourists prior to and in subsequent of the political upheaval of 2011. This book also details the country of origin of foreign tourists. However, this research will cover an in-depth research which is more focused than the book published by the Ministry of Tourism of the Arab Republic of Egypt. The difference between the former and the latter is in terms of the discussion of the tourism industry after the political upheaval of 2011, instead of focusing solely on the decline of visitors as written in Khuthat Tahrik Sari'at li Isti'adat alHarakat al-Siyahat li Mishri ba'da 25 Yanayir 2011. 
Another difference of the current research with the former is the position of the researcher which is going against the mainstream since this research includes other opinions than the two books. Those opinions will lead to the current state of a tourism industry after being affected by the political upheaval. This is in contrast to the book written by Siti Mutiah Setiawati [5] which is based on social and religious post-political strife in Lebanon. Another notable difference is that the current research covers a certain concern from a particular party, a decrease in visitors, the destruction of a number of attractions due to the difference in principle or the inability of the police, and the behavior change of souvenir merchants after the political upheaval. This is certainly different when compared with the book written by the Ministry of Tourism Arab Republic of Egypt (2012) which solely focuses on the decline of tourists.

Framework of thought is the idea underlying an effort to answer research questions, which covers the previously existed research, the formulation of concepts, and logic of research. Theory is the main underlying foundation of a research. A theory is born out of combination between a number of existing data and a particular system of thought. However, a theory is not necessarily true even though it has been supported by some data. On this account, the theory becomes the base for testing a hypothesis. In other words, the theory becomes the first milestone for a hypothesis to be verified [7, p. 28]. Such hypothesis test research is based on the deductive reasoning process.

In addition, this research applies Manners and Kaplan Theory [8, p. 77] as the basis for thinking. The theory argues that an organism in a social system of its parts is not only interconnected but also it is functional in terms of the stability, maintenance, and sustainability of the organism itself. The relationship between elements is owned by an organism that includes functional relationships, integration of cultural elements, and relationships between living things, all of which are in the field of tourism. The same also applies in tourism industry that is part of the social system in that all elements in it are not only interconnected but also functional in the stability, sustainability, and maintenance of the tourism industry. The tourism industry is an organism within a social system. However, due to the political upheaval, those parts of the tourism industry (organism) can no longer play a role in stability, sustainability, and maintenance. The social organization system which includes the tourism industry according to Sutrisno and Hendar Putranto [9, p. 29] includes elements of the theory of evolution in culture which refers to a slow change of stages.

\section{Method}

According to Tanudirjo [10, p. 1] method is the procedure to obtain information / data or to carry out a study on a certain case. This research applies two methods covering field research and literature research. As for the sampling method, it is commonly determined randomly, in a stratified method, or by way of census method after the field survey. However, in this research, the data is ultimately determined randomly. Random sampling is selected because not all provinces in the Arab Republic of Egypt have a well-known tourism attraction among foreign tourists so it is impossible to use the stratified method. The census method is not selected for time and cost constraints. The samples were taken while the researcher visited the research objects which include the Sharm al-Syaikh Beach, Alexandria Beach, Nile River, the Pyramids of Giza, the Tahrir Museum, the Saint Catherine Area, the Hanging Church, and the Heliopolis Area.

Data retrieval through the interview process is required in this study. The interviewees were not comprised of random people but people of competence and reliability in the theme related field [11, p. 225]. As for the method of presenting the data, it is known that field research requires a data presentation in accordance with the standards used. Some elements such as updating, (national or international) standard, accuracy, and precision are required in the presentation of data. Measurement methods. During the process of data analysis, the researcher also used Microsoft Excel as a computer program or software for processing and calculation of research data. Other measurements include the manual statistics. 


\section{Results}

There have been many parties concerning on the victory of Ikhwanul Muslimin both in the Legislative Election and in an Executive Election which make them the ruling Islamic political party post- the political upheaval of 2011. The aspect of economic, political, security and education always become the main concern of the observers and the opposition. In addition to those fields, tourism industry is also widely addressed since the Ikhwanul Muslimin shows its dominance both in the government and legislative. As previously explained in the previous chapters, many have a concern on the future of tourism sector since the ruling of Ikhwanul Muslimin. Tourism sector of the Arab Republic of Egypt is dominated by tourist destinations that may be deemed as unIslamic or not halal in the view of Islamic hardliners. In this line, there are some statements released by a number of prominent Ikhwanul Muslimin in tourism, as in the following.

Hisham Za'zu, a prominent Ikhwanul Muslimin who, when the government of Muhammad Mursi was given the post of Minister of Tourism in October 2012, has participated in a United Nations (UN) cooperation meeting in Macao, People's Republic of China. The culture and civilization of the Arab Republic of Egypt is a theme raised by Hisham during the meeting. The main theme of the meeting was the improvement of the performance of the tour guide. The meeting recommended the performance improvement of tour guides in the Arab Republic of Egypt [12, p. 4]. This was because after the political upheavals in 2011 there was a sharp decline of tourists visiting the Arab Republic of Egypt. The decline has an impact on the behavior of tour guides or souvenir merchants who seem to be depressed with the upheaval because their lives are highly dependent on the tourism industry. Such political instability certainly leads to the declining income. Hisham, together with the Ikhwanul Muslimin, is very concerned on the cultural and tourism sector of the Arab Republic of Egypt.

Another strategic policy of the Ministry of Tourism under Hisham $\mathrm{Za} \mathbf{Z u}$ 'is the plan to display thousands of ancient artifacts estimated to be thousands of years old. One of the ancient artifacts to be exhibited to tourists is derived from the tomb of Queen Meresankh III who is the grandson of King Khufu. This was revealed by Hisham on August 8, 2012.

Mohammed Mursi's right-hand man who was also given the position of Senior Deputy Ministry of Tourism and Head Section of Hotel Management and Tourism Village, Kasyif Osama al-'Asyra has been successful in hotel occupancy improvement programs in Cairo, Alexandria, Syarm al-Sheikh and Hurgada. The increase of hotel occupancy percentage of each city is respectively Cairo by $47 \%$, Alexandria $45 \%$, Syarm alSheikh 63\%, Hurgada 75\%, and Luxor and Aswan by 18\%. The noteworthy is an increase of hotel occupancy in Syarm al-Sheikh, located in the South Sinai Province, due to the policy of Ikhwanul Muslimin which is often regarded as going against the tourism object that seems to be un-Islamic or far from halalness.

The occupancy rate of hotels in all these cities witnesses a sharp decline when there was a political upheaval in 2011, especially in Luxor and Aswan, so it is no wonder that the two cities in Upper Egypt increased their occupancy after the revolution by only $18 \%$. This is because annually the two cities that are part of the Tourism Province will be very crowded in December and January, which is so-called Tourism Season. Meanwhile, the Arab Republic of Egypt Revolution took place at the beginning of the year which is very influential to the occupancy rate of hotels in Luxor and Aswan.

Increasing hotel occupancy by $20 \%$ also occurred in 286 resorts along the Nile River that stretches between the City of Cairo and the city of Aswan. The upsurge of the number of hotels was due to the policy of al-'Asyra as well as the improving quality and quantity of boat tours along the Nile River to support the existence of these resting places. The policy for improving the quality and quantity of Nile River boat tours by Ikhwanul Muslimin figures is a proof that they do not negatively view one of the world's longest river mainstay entertainments, the belly dance, which some considered as un-Islamic or unlawful.

The peak of this hotel occupancy surge occurred in February 2012 or exactly one year after Hosni

Mubarak stepped down from his post as President of the Arab Republic of Egypt (al-Hurriyah al-'Adaalah 19 
October, 2012: 6). It was noted that after the political upheaval of 2011 in the Arab Republic of Egypt, hotel occupancy rate was down drastically, but thanks to the policy of al-'Asyra, a cadre of Ikhwanul Muslimin, who resolved all those problems.

The pro-tourism policies of Ikhwanul Muslimin not only come from the less well-known leaders, but also from their supreme leader, the president of Muhammad Mursi. Mursi released his strategic policy in the tourism industry of the Arab Republic of Egypt by having a cabinet reshuffle to improve the economy as well as domestic security carried out on January 6, 2013. These two sectors are very important in a tourism industry. The newly formed Cabinet by Mursi is concentrated the improvement of the tourism industry and the effort to attract foreign investors to stabilize the Arab Republic of Egypt as it was before the political upheaval 2011 [13, p. 19].

Muhammad Mursi as the leader of the Ikhwanul Muslimin plays a pivotal role in the development of tourism industry in the Arab Republic of Egypt by establishing the Ministry of Antiquities after previously under the auspices of the Ministry of Culture under the name of the Archbishop's High Council. The separation is aimed to focus the work performance of the Ministry of Antiquities and the Ministry of Culture on their job description and to make them able to go hand in hand with the Ministry of Tourism.

It is true that ideologically, the Ikhwanul Muslimin is based on pure Islamic teachings, which is very conservative, exclusive, and rigid, but this is not directly proportional to the policy of Hassan al-Banna's organization which is liberal. The policies of Ikhwanul Muslimin figures tend to be more liberal in the field of tourism as they are willing to do anything as long as they can recover the tourism industry of the Arab Republic of Egypt as it used to be. The ideology of the Ikhwanul Muslimin turned out not to be in harmony with the policy of halal tourism as understood by the public. There are some indications that some of the Ikhwanul Muslimin's leaders have such a policy. The first indication is the desire of the economic recovery of the Arab Republic of Egypt which was severely disrupted by the political upheaval of 2011. The decline of tourists turned out to be a very big problem so the government under the Ikhwanul Muslimin tried hard to restore it. It is known that the biggest source of revenue for the Arab Republic of Egypt comes from the tourism sector, so the Ikhwanul Muslimin wants it to recover quickly as a way to improve the economy. This effort is not entirely successful because, according to the opposition, the Ikhwanul Muslimin government under the control of former president Muhammad Mursi failed in the economic recovery that led to a military coup dated on July 3, 2013. The second indication is the search for sympathy by the Ikhwanul Muslimin. Not all elements of the Arab Republic of Egypt like the governance style of the Ikhwanul Muslimin. These opponents threw various rumors to sack the Ikhwanul Muslimin government, including the sectarian issues, self-styled groups, economic downturns, and the declining rate of tourist visits to the country that the opposition argued as the effect of the policy of the Ikhwanul Muslimin that did not protect the non-halal tourist attractions.

The governments' of Ikhwanul Muslimin figures tried to address the issue by making some policies that indicate their concern about the tourism industry throughout the Arab Republic of Egypt. They held some programs in tourism and culture and they never incur any form of prevention or prohibition against various activities surrounding the tourism industry in the Arab Republic of Egypt regardless of its form. Another circulating issue is that the government under the Ikhwanul Muslimin will apply the operational hours of the sights. It is rumored that all tourist destinations are required to close before 10:00 PM. This is certainly a disadvantage, especially for the actors of the tourism industry such as Sharm al-Sheikh Beach. At 10.00 PM is the beginning or even the prime time for tourist destinations dominated by foreign tourists. However, at last, this all turned out to be unjustified negative issue.

There is no need to worry about the Islamic ideology of Ikhwanul Muslimin because it is not nearly as extremely Islamist as Salafi. It is evident from the fact that the administration of the Arab Republic of Egypt under the control of the Ikhwanul Muslimin was becoming more moderate. Thus, they believed that it was 
unnecessary to worry about their ideology. In this line, they expected that the foreign tourist dismiss their fear for visiting the Pyramids. The Ikhwanul Muslimin also argued that there was no explicit proof either from alQuran or al-Sunnah which explicitly contains the prohibition of tourism activities. The prohibition of the tourism industry means equal to the deprivation of thousands of jobs. This is of course not desired by the Ikhwanul Muslimin, let alone almost all the people of South Sinai Province and the Red Sea work in the field of tourism.

\section{Discussion}

The policy of the Ikhwanul Muslimin in the field of halal tourism is not as rigid as what many have thought. Many people believe that Muhammad Mursi's regime will fully implement halal tourism. This means that there will be a ban on liquor, a closure of belly dance entertainment on cruise ships along the Nile River, a closure of the tourist destinations of the Nazarene and Pharaoh Days, as well as restrictions on beach tourism that is identical with disobedience. All these things are indisputable. In fact, the Ikhwanul Muslimin is quite soft against the non-halal tourism.

For a country with a highly diverse population as Egypt, the issue of halal tourism policy is deemed as something interesting. Those opposing Islam may easily throw an adverse issue towards the closely related Muslim group government to disturb the stability of local politics. Thus, it is recommended that the government wisely deal with the issue. Otherwise, the government will falter. However, later it turned out that Muhammad Mursi's leadership ended tragically, but not because of the issue of halal tourism policy.

The concerns of tourism industry players against the dominance of the Ikhwanul Muslimin turned out to be all disputable. The group that is now banned in Arab Republic of Egypt through some of their officials did things contrary to the previously alleged issue. In fact, Ikhwanul Muslimin played an essential role and great service to the non halal tourism industry.

The book of Khuthat Tahrik Sari'at li Isti'adat al-Harakat al-Siyahat li Mishri ba'da 25 Yanayir 2011 which generally conclude that foreign tourists dropped dramatically by the political upheaval could raise the numbers of travelers' visits with various strategic policies of the Ikhwanul Muslimin. In general it can be said that there is no findings as previously expected. In fact, a number of data reinforce that the alleged extremely Islamist Ikhwanul Muslimin was rather too lenient in applying the concept of $100 \%$ halal tourism.

The implications of this study on political or tourism studies are that social movements and societies can influence the halal tourism policy by the government. This can be compared to the Kingdom of Saudi Arabia which very clearly implements Halal tourism at almost completely, especially in Makah and Medina.

The main limitation of the study that could have an effect on internal and external validity is the Ikhwanul Muslimin's movement itself. Now this Islamic Political Movement is widely banned in the Arab Republic of Egypt. Even in the Kingdom of Saudi Arabia it is included in the list of terrorist groups. However, it turned out that there are still many Islamic movement groups that resemble the Ikhwanul Muslimin's ideology, like Hamas in Palestine and Turkey's AKP. The latter group became the current ruler of Ankara with its phenomenal president Recep Tayip Erdogan. So there needs to be a comparison between the two Islamic Political Movements to strengthen the validity of this research.

It would be interesting to have a research on the political policy of Hamas on halal tourism in the Gaza Strip, Palestine even though the country has not been fully independent from the hands of Israel and the policy of Recep Tayip Erdogan. Such research will surely help us in formulating the concept of more humanized halal tourism.

\section{Conclusion}

It is conclusive that the issue that the Ikhwanul Muslimin does not take sides with the non-halal tourism industry is not true. Such is proven from a number of strategic policies in the field of tourism issued by some leaders of the Ikhwanul Muslimin who sits in government. First, they decided on the improving performance of the tour guide. Secondly, they increased hotel visit rate. Third, they had a cabinet reshuffle to increase security and search for foreign investors. Fourth, they separated the Ministry of Archeology from the Ministry of Culture which enabled the ministries to work together and be more focused in its job. A number of policies of Ikhwanul Muslimin figures are proof that the association founded by Hasan al-Banna is also liberal, especially in the field of tourism industry. Doing so they expected that the tourism industry of the Arab Republic of Egypt would 
quickly recover and there would be no more conflict or theft to the tourism destination collection because it requires a lot of funds for economic turnaround and tourism development such as the construction of the Great Museum in the Pyramids of Giza which was mainly funded by the tourism sector.

The Ikhwanul Muslimin was wise enough to implement a halal tourism policy, as they did not necessarily prohibit all non-halal tours. The Islamic teachings understood by the Ikhwanul Muslimin emphasize that the prohibition of liquor consumptions, the wearing of shorts, and the eating of pork and dogs are reserved for believers only, instead of to all humans. Chapter al-Kafirun verse 6 also clearly teaches them to respect other believers. So the Ikhwanul Muslimin did not close the tourist destinations that come from the Christian era as well as relics of Pharaoh for a number of these objects are not worshiped by Muslims. Halal tours are reserved for Muslims without having to force the adherence of other faith to follow. That is what the Ikhwanul Muslimin views about halal tourism.

It is recommended for all the people in the world including those in the Arab Republic of Egypt and the Republic of Indonesia that all elements within a community must always synergize with each other in all sectors of life, because it must be correlated with the tourism industry that leads to security and comfort. Secondly to the Government of the Arab Republic of Egypt, it is advisable that they stay away from a vortex of conflict because it is very impactful to the tourism industry as well as to the economy of the country. Thirdly for the Government of the Republic of Indonesia, it is advisable that they learn about the management of the tourism industry from the Arab Republic of Egypt because despite the political upheaval, each year the Arab Republic of Egypt on average is visited by more than 72 million foreign tourists. Geographically, the Republic of Indonesia is wider than the Arab Republic of Egypt, which means that it has more diverse attractions than that of the Egypt. However, it turns out that the number of foreign tourists of Republic of Indonesia is amounted to only 4 million people per year, much less than that of the Egypt. It is advisable that the government of both countries always maintain political and economic stability in order to maintain the stability of tourism industry.

The Government of the Republic of Indonesia also needs to gain knowledge from the stakeholders of the Arab Republic of Egypt on managing the world of tourism by providing halal tourism without having to eliminate the un-Islamic tourism destinations altogether. It is because not all foreign tourists are Muslims but foreign exchange within the country must continue to spin with a prospective source of income from the tourism sector. Of course it would be unwise to fully close Bali which would certainly be the end of the tourism industry in the Republic of Indonesia. However, we need to keep in mind that the major population of this country is Muslims who definitely want a halal tour. It is certain that the government needs to seek the win-win solution between both. Thus, it is required to learn from the Arab Republic of Egypt on the policy of halal tourism.

\section{Acknowledgements}

Many thanks are given to all people who help to finish and make this paper more accurate. They are Ministry of Tourism and Ministry of Antiquities of Arab Republic of Egypt who gave many information and data about this topic. Also the head of Department of Pharmacy, Faculty of Mathematics and Natural Sciences, Universitas Islam Indonesia with his support. And the head of Academic Development Board, Universitas Islam Indonesia who pays more attention with this research.

\section{References}

[1] T. Firmansyah, “Giliran Jaksa Incar Ikhwanul Muslimin,” Republika, p. 24, 17-Oct-2012.

[2] T. Firmansyah, "Inggris Gagal Bekukan Aset Rezim Mubarak,” Republika, Jakarta, p. 20, 04-Sep-2012.

[3] F. Kisihandi, "Mursi Buka Dialog Konstitusi," Republika, p. 7, 22-Dec-2012.

[4] T. Firmansyah, "Mursi Tetapkan Status Darurat," p. 20, 29-Jan-2013.

[5] S. M. Setiawati, Mekanisme Consociational dalam Penyelesaian Konflik Internal Lebanon. Yogyakarta: Elmatera Publishing dan Media Wacana., 2010.

[6] "Khuthat Tahrik Sari'at li Isti'adat al-Harakat al-Siyahat li Mishri ba'da 25 Yanayir 2011," Wizarat al-Siyahah Jumhuriyah Mishr al-'Arabiyah, al-Qahirah, 2012.

[7] C. Narbuko and A. Achmadi, Metodologi Penelitian. Jakarta: Bumi Aksara, 2009.

[8] D. Kaplan and R. A. Manners, Teori Budaya. Yogyakarta: Pustaka Pelajar, 2002. 
[9] M. Sutrisno and H. Putranto, Teori-Teori Kebudayaan. Yogyakarta: Kanisius, 2005.

[10] D. A. Tanudirjo, "Pengantar Teori Arkeologi," 2007.

[11] S. Endraswara, Metode, Teori, Teknik Penelitian Kebudayaan Ideologi Epistemologi, dan Aplikasi. Sleman: Pustaka Widyatama, 2006.

[12] M. Jaabir, "Misr Tusyaarik fii Mu'tamar al-Ittihaad al-Dauli li al-Mursyidiin al-Siyaahiin bi al-Shiin," al-Hurriyah al'Adalah, p. 4, 19-Oct-2012.

[13] F. Kisihandi, “Mursi Undang Oposisi Diskusikan Pemilu,” Republika, p. 19, 26-Feb-2013. 